Marquette University

e-Publications@Marquette

College of Education Faculty Research and

Publications

Education, College of

6-1-2004

Reflections on History and Quality Education

Harvey Kantor

University of Utah

Robert Lowe

Marquette University, robert.lowe@marquette.edu

Accepted version. Educational Researcher, Vol. 33, No. 5 (June 2004): 6-10. DOI. (C) 2004 SAGE

Publications. Used with permission. 


\title{
Reflections on History and Quality Education
}

\author{
Harvey Kantor \\ Department of Education, Culture, and Society \\ University of Utah \\ Salt Lake City, UT \\ Robert Lowe \\ Department of Educational Policy and Leadership Studies \\ Marquette University \\ Milwaukee, WI
}

This essay questions the commonly held assumption that schools today are worse academically than they were in the past. It argues that schools have seldom been chiefly interested in intellectual inquiry. Nor have they ever been committed to providing a quality intellectual education to all students. We argue that if history has anything to tell us about quality education today, it is not that we must try to recapture a lost age of academic excellence but that we cannot create truly excellent schools without addressing the inequities that have long been embedded in them or without understanding how those marginalized by the educational system have struggled to confront inequities.

Any discussion of what history might tell us about quality education runs the risk of presentism: seeing the past through the preoccupations of the present. Most educational historians who wrote 
before the 1960s, for example, typically failed to view the past on its own terms. Eager to create a sense of esprit de corps among public school leaders yet aware of the poor quality of most schooling in earlier periods, they were guilty of a particular kind of presentism that saw the past- sometimes going all the way back to the Puritan education laws of the 17th century-as inexorably leading to the crowning triumph of present-day education. The past merely became the "present writ small," to use Bernard Bailyn's (1960) phrase. ${ }^{1}$ Over the past two decades, however, the dominant trope has not been a triumphal one. It has been one of loss and decline or, to invert Bailyn, the present as the past writ small. We see this not only in A Nation at Risk (National Commission on Excellence in Education, 1983), which invoked a lost age of academic excellence to rally the country to its vision of higher academic standards and more discipline-based course requirements, but also in studies conducted by scholars from various disciplines, including several historians.

Though certain things about schooling in the United States may well be worse today than in the past, there are several problems with this way of thinking. One potential problem is the association of such a view with changes that accompany broader access to education by the less economically privileged, although this is hardly unique to the present. In fact, it first surfaced at least as far back as the 18th century when, as Bill Reese (1995) has pointed out, the establishment of writing schools was seen as debasing the standards of Boston Latin. It also can be seen later when the spread of district schools was perceived as a declension from the supposedly superior town schools. From the perspective of educational history, however, what is troublesome about the current popularity of the trope of decline is not just that it runs the risk of invoking history on behalf of privilege. More fundamentally, if quality education is taken to mean a strong academic curriculum taught by engaged, engaging, and well-educated teachers in schools committed to the promotion of intellectual development, we simply cannot locate much of it in the past. To a significant extent, this has been true of the education of the wealthy and the poor alike, though the former certainly have had greater access to academic subjects.

Consider, for example, the Puritan elite who attended Harvard in the 1640s. It is unlikely that they derived much of an academic education from the ministrations of President Dunster, who taught the

Educational Researcher, Vol. 33, No. 5 (June 2004): pg. 6-10. DOI. This article is @ SAGE Publications and permission has been granted for this version to appear in e-Publications@Marquette. SAGE Publications does not grant permission for this article to be further copied/distributed or hosted elsewhere without the express permission from SAGE Publications. 
entire curriculum. Even if they did, however, such an education was not considered to be as important as the cultivation of order and piety, as the Harvard statutes made clear (J. Quincy, cited in Tyack, 1967). This emphasis did not change substantially over the next 250 years, either at Harvard or anyplace else. Frederick Rudolph (1962) observed that despite the proliferation of courses, the greater specialization of faculty, and the secularization of higher education over time, intellect seldom outranked piety as a consideration in the recruitment of faculty at most colleges and universities, and, at least until the end of the 19th century, teaching in the academic disciplines remained profoundly underdeveloped relative to the present. If one individual could no longer offer the entire college curriculum, one person could still be responsible for an entire discipline. In 1869, for example, Harvard's history professor, according to Lawrence Levine (1993, p. 855), "was responsible for ancient, medieval, and modern history and American constitutional history, all of which he taught out of textbooks."

While Harvard prepared a few boys for the ministry and other professions, the one-room district school became the norm for most young people between the revolutionary period and the mid-19th century. Though surely an improvement over home schooling and the other informal educational arrangements that predominated in the 18th century, these schools clearly did not offer what we today would call a quality education. In district schools, a typically untrained teacher met what Joseph Kett (1977; see also Kaestle, 1983) called "a promiscuous assemblage" of students with a curriculum made up of whatever books students brought from home. These schools could also be quite chaotic, as teachers struggled, often unsuccessfully, to assert authority over their students. According to Merle Curti (1935/1978), in 1837 in Massachusetts, where the state of education was probably the most advanced, "some three hundred teachers were driven out of their schools by unruly and riotous pupils over whom, in spite of the prevalent use of the whip, they were unable to keep any semblance of order" (p. 107). ${ }^{2}$ After the mid-19th century, teachers' gender shifted primarily from male to female, textbooks became more uniform, and teachers were somewhat better educated; despite these changes, however, the typical 19th-century district school seldom became a bastion of quality education. ${ }^{3}$

Educational Researcher, Vol. 33, No. 5 (June 2004): pg. 6-10. DOI. This article is (C SAGE Publications and permission has been granted for this version to appear in e-Publications@Marquette. SAGE Publications does not grant permission for this article to be further copied/distributed or hosted elsewhere without the express permission from SAGE Publications. 
On the other hand, popular recollections suggest that rural schools did nurture a sense of community that is conspicuously lacking in many schools today. Even then, however, "the circle of the we" in these schools, to borrow David Hollinger's (1995, p. 106) phrase, could be remarkably small. In fact, because local fractiousness often led to the mitotic division of schools, many constituted little more than home schooling for a family or two. Wayne Fuller (1982) noted that, late in the 19th century, "the superintendent of public instruction in Wisconsin reported that school districts were so small that 183 schools had no more than five students each, 853 no more than ten, and 3,523 , almost three-fifths of the whole, had an average attendance of no more than twenty children" (p. 110).

It is important not to overstate the inattentiveness to quality education, however. Quality certainly was a concern for Horace Mann and other mid-19th-century advocates of the common school. Mann, for example, supported graded classrooms, uniform texts, normal schools for training teachers, an end to corporal punishment, and pedagogical methods that would emphasize understanding rather than rote memorization of disconnected bits of information. In fact, so committed was Mann to improving the academic quality of education that historian Lawrence Cremin (1957, p. 24) chastised him for failing to recognize "that quality is not the only test of a school." Yet, notwithstanding Cremin's admonishment, Mann too emphasized that deportment and moral qualities (e.g., temperance, frugality, honesty, and a respect for hard work) mattered at least as much as intellect, not just in the education of students but in the selection of teachers as well. "If none but teachers of pure taste, of good manners, of exemplary morals, had ever gained admission to our schools," he wrote in 1840, "neither the school rooms, nor their appurtenances would have been polluted, as some of them are now, with such ribald inscriptions, and with the carvings of such obscene emblems, as would make a heathen blush" (cited in Cremin, 1957, p. 52). The degree to which teachers were up to the task of providing moral and intellectual enlightenment is debatable, but the former, enshrined in the ubiquitous McGuffey Readers (about 60 million copies of which were sold between 1870 and 1890) and other texts, was unarguably the main interest of 19th-century common schools (Kaestle, 1983; see also Tyack, 2003, chap. 1).

Educational Researcher, Vol. 33, No. 5 (June 2004): pg. 6-10. DOI. This article is (C SAGE Publications and permission has been granted for this version to appear in e-Publications@Marquette. SAGE Publications does not grant permission for this article to be further copied/distributed or hosted elsewhere without the express permission from SAGE Publications. 
Yet, whatever the case for quality education in the 19th century, scholars today who emphasize decline typically trace its starting point to a later period, especially focusing on the time subsequent to an apparent golden age of urban schools at the end of the 19th century and the beginning of the 20th century. Those of this persuasion tend to view the 1893 Report of the Committee of Ten-which argued that all high school students should receive a purely academic education for however long they remained in school-as symbolic of this golden age. 4 Yet, this too is an excessively presentist reading of the past. Although the committee did resist pressure to water down the academic content of the high school curriculum by opposing the addition of industrial education and domestic science, its recommendation to include modern academic subjects at the expense of an exclusive focus on the classics and its advocacy of the elective system were viewed by many at the time as sharp departures from what was then the orthodox view of academic excellence. ${ }^{5}$

Nonetheless, it is true that most urban high schools in the late 19th and early 20th centuries contained a considerable dose of academics. In many cities, even the manual arts high school was heavily academic. In Milwaukee, for instance, the curriculum in the manual training course required 3 years of mathematics; 2 years of science, including a full year of physics; a semester each of English literature and American literature; and electives that included American classics, English history, and German history (Milwaukee School Board, 1899). This compares favorably with what many states require today for high school graduation after two decades of agitation for higher academic standards and increased academic course requirements.

Teachers in most urban high schools were also extraordinarily well educated for the time. In 1903, for example, the school board president in Milwaukee claimed that the high schools in his city "were filled with experienced graduates of such institutions as the University of Wisconsin, De Pauw University, Harvard University, Smith College and Vassar College" (Milwaukee School Board, 1903, p. 372). Indeed, some had once been college professors, and some would later become professors. An example of the latter was Harriet Bell Merrill, who graduated summa cum laude from the University of Wisconsin in 1890 and received an MS from that university in 1900 (see Hartridge, 1997). ${ }^{6}$ After teaching high school from 1900 to 1910 in the Milwaukee

Educational Researcher, Vol. 33, No. 5 (June 2004): pg. 6-10. DOI. This article is (C SAGE Publications and permission has been granted for this version to appear in e-Publications@Marquette. SAGE Publications does not grant permission for this article to be further copied/distributed or hosted elsewhere without the express permission from SAGE Publications. 
Public Schools, she left to become an assistant professor of zoology at the University of Wisconsin, did extensive research in South America, and discovered a species of protozoa that would be named after her. She died at the age of 52 while pursuing a doctorate at the University of Illinois.

Yet, if this represented a time when high schools were staffed by exceptionally well-educated teachers who were committed to an academic agenda, it is also the case that only a few students took advantage of-or were able to take advantage of-this commitment. Indeed, though the trope of decline implies that 19thcentury high schools were committed to an ideal of academic excellence for all students, prior to the turn of the 20th century, high schools remained minority institutions, patronized mainly by a small number of middleand upper-middle-class young men whose families could afford to forgo their labor while they attended school and by young women who hoped that a high school diploma would lead to a career in teaching. Everyone else-about $80 \%$ to $90 \%$ of the eligible age group in $1900-$ left school before the ninth grade, receiving no more exposure to academic knowledge than the little that was provided in the typical rural district or urban elementary school (Reese, 1995, pp. 176-181).

Because high schools became more differentiated as they became more open, this connection between academic knowledge and middle-class status persisted after 1900, even as high school attendance expanded. In fact, although the total number of students enrolled in academic classes increased after the turn of the century, the proportion of all high school students in academic classes began to go down, since access to the academic track remained limited to a few while the rest of the curriculum increased in importance for everyone else. Yet, the notion that this represented a betrayal of the schools' commitment to academics is difficult to sustain once we recognize that high school attendance had in effect long been limited to a select group of students. From the perspective of the 19th century, the expansion of less academic curricula appears not so much as an expression of academic decline as a way for a relatively elite population to preserve their privileged standing as the poor and the working class pressed against their institutions. ${ }^{7}$

That access to academics has long been a mark of privilege does not mean, however, that these courses have involved students in an intellectually meaningful way, even in the late 19th and early 20th

Educational Researcher, Vol. 33, No. 5 (June 2004): pg. 6-10. DOI. This article is (C SAGE Publications and permission has been granted for this version to appear in e-Publications@Marquette. SAGE Publications does not grant permission for this article to be further copied/distributed or hosted elsewhere without the express permission from SAGE Publications. 
centuries. In fact, though first-hand accounts of teachers and high school classrooms are sparse, the evidence we do have-such as Robert and Helen Lynd's (1929) famous study of 1920 s school life in Muncie, Indiana-suggests just the opposite. Far from being the kind of intellectually engaging experience the trope of decline imagines, the Lynds found, for example, that teaching and learning in Muncieespecially in academic courses-were "ordeals" from which teachers and students alike would have been glad to escape, much as they were two decades earlier in New York City, where, according to Larry Cuban's (1993) imaginatively researched book How Teachers Taught, teaching and learning in New York's high schools consisted chiefly of "rapidfire teacher questioning" and brief memorized responses that did little to engage or inspire.

As tedious as the academic work in high schools might have been, conditions in early-20th-century urban elementary schoolswhere most city children ended their educational careers-were even worse. In these schools, it was common for as many as 70 or 80 students to be crowded into a single classroom where they were governed by teachers who, though better educated than their rural counterparts, typically had no more than a high school education and who relied on harsh discipline to control their students and on mechanical methods of instruction to teach them (Cuban, 1993; Rice, 1893). Not surprisingly, children often disliked school intensely. In 1908, Helen Todd, a factory inspector in Chicago, surveyed 500 underaged children working in the city's factories doing jobs such as lacquering canes; 412 of these children told her that they preferred such labor to being in school (Todd, 1913).

If anything, conditions improved over the first half of the 20th century. Not only in suburban school systems but in many urban systems as well, elementary school class sizes decreased, discipline became less harsh, and teachers became better educated. In most systems, however, classroom instruction improved only marginally. According to Cuban (1993), though many teachers modified their teaching practices to include discussion and small group activities, recitation remained the dominant form of instruction, with the majority of class time spent working on textbook assignments.

Absent more engaging subject matter or inspiring instruction, it is hardly surprising to discover, as the Lynds (1929) and other researchers did, that few students have ever rated academic learning

Educational Researcher, Vol. 33, No. 5 (June 2004): pg. 6-10. DOI. This article is @ SAGE Publications and permission has been granted for this version to appear in e-Publications@Marquette. SAGE Publications does not grant permission for this article to be further copied/distributed or hosted elsewhere without the express permission from SAGE Publications. 
a top priority in their lives. The students in Muncie, for example, were much more concerned about extracurricular activities and promoting the "Bearcat" spirit than they were about their classes. Even highachieving students told the Lynds that they did not put much effort into their classes, and they seldom saw academics as the chief reason for going to school. Neither, for that matter, did their parents. According to the Lynds, they too viewed social skills and athletics as more important than academics.

This does not mean that parents and students in the first part of the 20th century discounted the importance of academic success or saw no value in education. To the contrary, the Lynds (1929) reported that Muncie's residents valued few things as much as they valued education. But few of them valued education or academic achievement for the learning it represented. More important to them was the social status it was coming to symbolize and the economic advantage it conferred in a society where college attendance was becoming increasingly important in the competition for the best jobs the economy had to offer. ${ }^{8}$

Muncie, Indiana, in the 1920s may not be representative of the entire United States. But the situation does not appear to have been much different elsewhere, at least not according to Gerald Grant's (1988) history of Hamilton High in the 1950s. In his book, Grant lauds this school for its decorum, its high academic expectations, and its excellent academic program. Its all-White, mostly middle-class students were motivated to be accepted to good colleges so that they might succeed later in life, as were the students the Lynds observed in the 1920s. However, at least by Grant's account, this did not translate into any more enduring intellectual engagement either inside or outside the classroom than it had in Muncie. One politically active student complained that despite the academically rigorous course of study, the school seemed more interested in enforcing conformity than in fostering the acquisition of knowledge or active intellectual inquiry.

Of course, there have been schools in the past where classes were imaginatively taught and students were encouraged to make reading and thinking about intellectual issues part of their lives, much as the trope of decline maintains. But if high-quality schools existed in ways that would appeal to the standards of the present as well as the past, they typically were the preserves of elites. John Dewey (1900, p. 3) famously stated, "What the best and wisest parent wants for his

Educational Researcher, Vol. 33, No. 5 (June 2004): pg. 6-10. DOI. This article is @ SAGE Publications and permission has been granted for this version to appear in e-Publications@Marquette. SAGE Publications does not grant permission for this article to be further copied/distributed or hosted elsewhere without the express permission from SAGE Publications. 
own child, that must the community want for all of its children. Any other ideal for our schools is narrow and unlovely; acted upon, it destroys our democracy." If such a parent were poor, however, he (or she) would not have had access to Dewey's Laboratory School at the University of Chicago, an extraordinary effort in progressive education that was blessed with abundant financial as well as human resources. In 1903, for example, the student-teacher ratio was 6 to 1 , and the student-graduate student ratio was 10 to $1 .{ }^{9}$ Indeed, although the Laboratory School was an impressive experiment in what quality teaching and learning might look like, it served only to underscore the appalling lack of quality that characterized the education most children received in the Chicago public schools.

Dewey's school was by no means the only extraordinary one that dots the historical horizon, nor do we find such schools exclusively in places that adhered to progressive principles. To varying degrees, however, they have been exclusive. At the secondary level, this has been the case for suburban schools in places like New Trier, Scarsdale, and Newton; prep schools like Exeter and Andover; and AfricanAmerican high schools like Frederick Douglass in Baltimore, Booker T. Washington in Atlanta, and M Street (later Dunbar) in Washington, D.C. ${ }^{10}$ The last three schools, whose years of prominence predated the time that most African Americans had access to high school, certainly lacked resources in comparison with elite White schools, but, in an ironic twist, they benefited from discrimination in the labor market, which enabled them to attract an exceptionally well-educated group of Black teachers.

Historians, then, can mine the past for examples of fine schools whose quality is more or less transcendent, and what they discover about the qualities of these institutions can be used to inform the way we think about creating schools in the future. ${ }^{11}$ From our perspective, however, history uncovers much more inequality than quality. Indeed, in our view, if history has anything to tell us about quality education, it is not that we must somehow try to recapture a time when schools were supposedly better than they are today or that we must try to recreate the conditions that made possible the existence of a few truly exceptional schools. It is, rather, that we cannot create truly excellent schools without confronting the inequities that have long been deeply embedded in them or without understanding how those long marginalized by the educational system have contested such

Educational Researcher, Vol. 33, No. 5 (June 2004): pg. 6-10. DOI. This article is (C SAGE Publications and permission has been granted for this version to appear in e-Publications@Marquette. SAGE Publications does not grant permission for this article to be further copied/distributed or hosted elsewhere without the express permission from SAGE Publications. 
inequalities in ways that have promoted greater access and, at times, quality as well.

It is the absence of this kind of understanding, we think, that accounts for the intense animosity the trope of decline reserves for the educational struggles of the late 1960s. In particular, African Americans' struggles to alter the power relationships and curricula of schools have been viewed as disruptive and divisive outbursts that have degraded the educational enterprise rather than as efforts both to expand access to academic knowledge for those long denied access to it and to redefine the curricular canon to include the views and perspectives of those excluded from it. Instead of creating turmoil that accelerated educational decline, we think that this activism represented the extension of a long alternative tradition of valuing and battling for quality education announced at the turn of the 20th century by W. E. B. Du Bois (1969). In Souls of Black Folk, Du Bois wrote, "I sit with Shakespeare and he winces not. Across the color line I move arm and arm with Balzac and Dumas ... . I summon Aristotle and Aurelius and what soul I will, and they come all graciously with no scorn or condescension. . . . Is this the life you grudge us, O knightly America?" (p. 139) Here is a claim for ownership of what should have been a common legacy (and, of course, Du Bois became a prominent advocate of African-American studies as well), but it was a legacy denied in order to subordinate African Americans (see, especially, Anderson, 1988). When we think of quality education in the past, consequently, we think foremost of this aspiration for the liberal artsone tied to liberation and the embattled efforts of not only African Americans, but Latinos and other people of color, as well, to institutionally embody it.

\section{Notes}

1. In his recent book, American Educational History Revisited, Milton Gaither challenges Bailyn's characterization of educational historiography. He argues that educational historians prior to 1960 were not nearly as isolated from the mainstream of historical writing as Bailyn implied. Nor were they as neglectful of the cultural context surrounding education as Bailyn claimed. On our reading, however, Gaither does not seriously dispute the Whiggish assumptions that have informed most, though not all, educational historiography.

Educational Researcher, Vol. 33, No. 5 (June 2004): pg. 6-10. DOI. This article is @ SAGE Publications and permission has been granted for this version to appear in e-Publications@Marquette. SAGE Publications does not grant permission for this article to be further copied/distributed or hosted elsewhere without the express permission from SAGE Publications. 
2. See also Kett (1977, p. 47) on the problem of authority in rural district schools.

3. For a more positive view of the quality of education in rural schools, see Fuller (1982, chaps. 9 and 10).

4. For this view of the Report of the Committee of Ten, see Ravitch (2000, chap. 1) and Angus and Mirel (1999, pp. 8-10).

5. On the context of this report, see Krug (1964, chap. 3).

6. Milwaukee was not unusual in this regard. In the late 19 th and early 20th centuries, high schools in many cities typically had a large number of college-educated teachers. See, for example, David Labaree's (1988, chap. 5) description of the teachers at Philadelphia's Central High School.

7. On the connections among the expansion of high school attendance, curricular differentiation, and the persistence of inequality, see Cohen and Neufeld (1981).

8. On the increasing social and economic importance youth place on education, see Hollingshead (1949, chap. 8).

9. There were 140 students, 23 teachers, and 10 graduate students (see Westbrook, 1991, p. 97).

10. These are some of the schools discussed in Thomas Sowell's (1976) famous essay, "Patterns of Black Excellence."

11. On African-American education, for example, see especially Perry (2003, pp. 87-108).

\section{Authors}

Harvey Kantor is a professor in the Department of Education, Culture, and Society at the University of Utah, Salt Lake City, UT 84112; harvey.kantor@ed.utah.edu. His research interests are the history of education and social policy.

Robert Lowe is a professor in the Department of Educational Policy and Leadership Studies, Marquette University, PO Box 1881, Milwaukee, WI 53201; robert.lowe@marquette.edu. His research interest is the history of education.

Educational Researcher, Vol. 33, No. 5 (June 2004): pg. 6-10. DOI. This article is (C SAGE Publications and permission has been granted for this version to appear in e-Publications@Marquette. SAGE Publications does not grant permission for this article to be further copied/distributed or hosted elsewhere without the express permission from SAGE Publications. 
NOT THE PUBLISHED VERSION; this is the author's final, peer-reviewed manuscript. The published version may be accessed by following the link in the citation at the bottom of the page.

\section{References}

Anderson, J. (1988). The education of Blacks in the South, 1860-1935. Chapel Hill: University of North Carolina Press.

Angus, D., \& Mirel, J. (1999). The failed promise of the American high school, 1890-1995. New York: Teachers College Press.

Bailyn, B. (1960). Education in the forming of American society. New York: Vintage Books.

Cohen, D. K., \& Neufeld, B. (1981). The failure of high schools and the progress of education. Daedalus, 110, 69-90.

Cremin, L. A. (1957). The republic and the school: Horace Mann and the education of free men. New York: Teachers College Press.

Cuban, L. (1993). How teachers taught: Constancy and change in American classrooms, 1880-1990. New York: Teachers College Press.

Curti, M. (1978). The social ideas of American educators. Totowa, NJ: Littlefield, Adams. (Original work published 1935)

Dewey, J. (1900). The school and society. Chicago: University of Chicago Press.

Du Bois, W. E. B. (1969). Souls of Black folk. New York: New American Library.

Fuller, W. (1982). The old country school: The story of rural education in the Middle West. Chicago: University of Chicago Press.

Gaither, M. (2003). American educational history revisited. New York: Teachers College Press.

Grant, G. (1988). The world we created at Hamilton High. Cambridge, MA: Harvard University Press.

Hartridge, M. H. (1997). The anandrous journey: Revealing letters to a mentor. Amherst, WI: Amherst Press.

Hollinger, D. A. (1995). Postethnic America: Beyond multiculturalism. New York: Basic Books.

Hollingshead, A. (1949). Elmtown's youth: The impact of social class on adolescents. New York: Wiley.

Kaestle, C. F. (1983). Pillars of the republic: Common schools and American society, 1780-1860. New York: Hill \& Wang.

Kett, J. F. (1977). Rites of passage: Adolescence in America. New York: Basic Books.

Krug, E. (1964). The shaping of the American high school, 1880-1920. New York: Harper \& Row.

Labaree, D. (1988). The making of an American high school: The credentials market and the Central High School of Philadelphia, 1838-1939. New Haven, CT: Yale University Press.

Levine, L. W. (1993). Clio, canons, and culture. Journal of American History, $80,849-867$.

Educational Researcher, Vol. 33, No. 5 (June 2004): pg. 6-10. DOI. This article is @ SAGE Publications and permission has been granted for this version to appear in e-Publications@Marquette. SAGE Publications does not grant permission for this article to be further copied/distributed or hosted elsewhere without the express permission from SAGE Publications. 
NOT THE PUBLISHED VERSION; this is the author's final, peer-reviewed manuscript. The published version may be accessed by following the link in the citation at the bottom of the page.

Lynd, R. S., \& Lynd, H. M. (1929). Middletown: A study in modern American culture. New York: Harcourt, Brace \& World.

Milwaukee School Board. (1899). Proceedings of the Milwaukee School Board, July 11, 1899. Milwaukee, WI: Author.

Milwaukee School Board. (1903). Proceedings of the Milwaukee School Board, May 4, 1903. Milwaukee, WI: Author.

National Commission on Excellence in Education. (1983). A nation at risk. Washington, DC: U.S. Department of Education.

Perry, T. (2003). Achieving in post-civil rights America: the outline of a theory. In T. Perry, C. Steele, \& A. Hilliard III (Eds.), Young, gifted, and Black: Promoting high achievement among African-American students (pp. 87-108). Boston: Beacon Press.

Ravitch, D. (2000). Left back: A century of failed school reforms. New York: Simon \& Schuster.

Reese, W. (1995). The origins of the American high school. New Haven, CT: Yale University Press.

Rice, J. M. (1893). The public school system of the United States. New York: Century.

Rudolph, F. (1962). The American college and university: A history. New York: Alfred A. Knopf.

Sowell, T. (1976). Patterns of Black excellence. The Public Interest, 43, 2658.

Todd, H. (1913, April). Why children work: The children's answer. McClure's Magazine, pp. 73-74.

Tyack, D. B. (1967). Turning points in American educational history. Lexington, MA: Xerox College Publishing.

Tyack, D. (2003). Seeking common ground: Public schools in a diverse society. Cambridge, MA: Harvard University Press.

Westbrook, R. (1991). John Dewey and American democracy. Ithaca, NY: Cornell University Press.

Educational Researcher, Vol. 33, No. 5 (June 2004): pg. 6-10. DOI. This article is @ SAGE Publications and permission has been granted for this version to appear in e-Publications@Marquette. SAGE Publications does not grant permission for this article to be further copied/distributed or hosted elsewhere without the express permission from SAGE Publications. 